\title{
Evaluating the Sunshine Duration Characteristics in Association with Other Climate Variables
}

\author{
Mine Tulin Zateroglu ${ }^{1 *}$ \\ ${ }^{1}$ Cukurova University, Vocational School of AOSB Technical Sciences, Department of Electrical and Energy, Adana, Turkey (ORCID: 0000-0002-1050-6174)
} (International Symposium on Multidisciplinary Studies and Innovative Technologies (ISMSIT) 2021 - 21-23 October 2021)

(DOI: 10.31590/ejosat.1022639)

ATIF/REFERENCE: Zateroglu, M.T. (2021). Evaluating the Sunshine Duration Characteristics in Association with Other Climate Variables. European Journal of Science and Technology, (29), 200-207.

\begin{abstract}
Many processes such as for industrial production, heating, cooling, health, education and etc. are depended on and use the energy. In recent years, the consumption of energy has been increased over the world. Fossil energy sources cannot meet the increase in energy demand. So, renewable energy sources especially solar energy become important in this way. The applications with solar energy present clear and environment friendly systems. Sunshine duration which is used for estimating the solar energy is very crucial parameter for human life. Climate variables in atmospheric environment have influences on sunshine duration. This study aims to demonstrate the relations between daily sunshine duration and other climate variables such as cloud amount, atmospheric pressure, maximum air temperature, minimum air temperature, relative humidity, precipitation and wind speed. The data of all climate variables were obtained from the measurements of ground based observation station belonging to the Turkish State Meteorological Service. The long term records based on daily measurements were examined for Rize meteorological station. The daily observation values for sunshine duration and other climate variables were transformed to mean montly values. A 51 years (1960-2010) database was statistically analyzed by using the method named as Pearson Correlation Analysis (\%95 confidence interval). The obtained results over this analysis were shown that sunshine duration was associated with other climate variables. The grade of these relations was changed according the different time periods. The amount of relations were obtained generally in moderate, good and weak degrees as statistically significant $(\mathrm{p}<0.05)$. Sunshine duration was highly negatively correlated with cloud amount generally except the exceptional circumstances such as moderate for December. The correlations for sunshine duration and the other climate variables were found as negatively for relative humidity, atmospheric pressure and precipitation and positively for wind speed, maximum and minimum air temperature.
\end{abstract}

Keywords: Sunshine Duration, Climate variables, Pearson Correlation Analysis.

\section{Güneşlenme Süresi Karakteristiklerinin Diğer İklim Değişkenleri İle İlişkili Olarak Değerlendirilmesi}

$\ddot{O} \mathbf{z}$

Endüstriyel üretim, ısıtma, soğutma, sağlık, eğitim vb. birçok süreç enerjiye bağımlıdır ve enerjiyi kullanır. Son yıllarda tüm dünyada enerji tüketimi artmıştır. Fosil enerji kaynakları, enerji talebindeki artışı karşılayamamaktadır. Dolayısıyla yenilenebilir enerji kaynakları, özellikle güneş enerjisi bu durumda önem kazanmaktadır. Güneş enerjisi ile yapılan uygulamalar temiz ve çevre dostu sistemler sunmaktadır. Güneş enerjisinin tahmininde kullanılan güneşlenme süresi, insan yaşamı için çok önemli bir parametredir. Atmosferik ortamdaki iklim değişkenlerinin güneşlenme süresi üzerinde etkileri bulunmaktadır. Bu çalışma, günlük güneşlenme süresi ile bulut miktarı, atmosfer basıncı, maksimum hava sıcaklığı, minimum hava sıcaklığı, bağıl nem, yağış ve rüzgar hızı gibi diğer iklim değişkenleri arasındaki ilişkileri ortaya koymayı amaçlamaktadır. Tüm iklim değişkenlerine ait veriler, Devlet Meteoroloji Genel Müdürlügü̈'ne ait yer tabanlı gözlem istasyonunun ölçümlerinden elde edilmiştir. Rize meteoroloji istasyonu için günlük ölçümlere dayalı uzun dönem kayıtları incelenmiştir. Güneşlenme süresi ve diğer iklim değişkenleri için günlük gözlem değerleri aylık ortalama değerlere dönüştürülmüştür. 51 yıllık (1960-2010) bir veri tabanı, Pearson Korelasyon Analizi olarak adlandırılan yöntem kullanılarak istatistiksel olarak (\%95 güven aralığı) analiz edilmiştir. Bu analiz üzerinden elde edilen sonuçlar, güneşlenme süresinin diğer iklim değişkenleri ile ilişkili olduğunu göstermiştir. Bu ilişkilerin derecesi farklı zaman dilimlerine göre değiş̧ş̧tir. İlişki düzeyleri genel olarak orta, iyi ve zayıf derecelerde istatistiksel olarak anlamlı olarak elde edilmiştir $(\mathrm{p}<0.05)$. İlişki düzeyinin orta düzeyde elde edildiği Aralık ayı gibi istisnai durumlar dışında, genel olarak güneşlenme süresi bulut miktarı ile yüksek oranda negatif korelasyon göstermiştir. Güneşlenme süresi ile diğer iklim değişkenleri arasındaki korelasyonlar bağıl nem, atmosfer basıncı ve yağış için negatif, rüzgar hızı, maksimum ve minimum hava sıcaklığ

Anahtar Kelimeler: Güneşlenme Süresi, İklim Değişkenleri, Pearson Korelasyon Analizi.

\footnotetext{
* Corresponding Author: Cukurova University, Vocational School of AOSB Technical Sciences, Department of Electrical and Energy, Adana, Turkey, ORCID: 0000-0002-1050-6174, mtzateroglu@,cu.edu.tr
} 


\section{Introduction}

Energy demand has increased over the world in last few decades because of its usage and consumption everywhere. The need for energy which has a crucial place in the social and economic sense due to industrialization, population growth, public works, growth rate and urbanization, is increasing day by day. The energy issue is considerable in terms of raising the people's living standards and healthy economic growth. At this point, renewable energy sources have become very important for the sustainability of energy generation and usage. There is no doubt that energy is necessary for the earth and its inhabitants. Solar energy is the main energy source for our planet and widely preferred as renewable energy source in applications. Solar energy has great potential and is more clear for the environment than the others.

As solar energy is important, it is also important to know the duration of the energy reaching the earth which is called as sunshine duration. For a given location, it is crucial to know the amount of solar radiation that has effect on the atmosphere via physical forms. Besides, solar radiation is related to sunshine duration by the Angström-Prescott formula which predicts the quantity of solar radiation. Sunshine duration which is utilized in many areas e.g. power plant planning, agricultural works, etc. is measured in the ground based observation stations over the world for many years. The measurements of sunshine duration are existent and reliable. On the other hand, for such cases e.g. absence of measurement station and remote areas, sunshine duration measurement is not provided so its value is estimated via statistical methods. In this way, the quantity of sunshine duration can be obtained by operating the several climate variables. These variables may be different owing to the topography and the sessional climatological alterations. In acccordance with the researches, sunshine duration was found as related to climate variables. Expressed by that cloud cover was associated with sunshine hours negatively (Robaa, 2008; Sanchez-Lorenzo et al., 2009; Essa\&Etman, 2004; Palle\&Butler, 2001; Weber, 1994; Angell et al., 1984). Additionaly relative humidity affects sunshine duration reversely (Aksoy, 1999; You et al., 2010; Yang et al., 2009a). In contrast to cloud cover and relative humidity, atmospheric pressure and wind speed have influences on sunshine hours positively (Sanchez-Lorenzo et al., 2009; Yang et al., $2009 a \& 2009 b$ ). Besides the amount of precipitation has negative effects on sunshine hours (You et al., 2010). Further, the concentrations of air pollutants have influences on sunshine hours. Zateroglu (2021a) expressed the relationships between sunshine duration and several air pollutants. Also, sunshine duration and other climate elements have interactions with air pollutants in atmosphere and related to each other (Zateroglu, 2021b). Moreover, some parameters such as latitude and atmospheric circulations affect the sunshine hours spatially (Aksoy, 2010).

The climate data for Rize spreading over the period 19602010 was obtained from the ground-based meteorological station measuring by Turkish State Meteorological Service. The data was measured by the heliograph for sunshine duration, by visual observation for cloud cover, by dry-bulb thermometers for air temperature, by barometer for atmospheric pressure, by pluviograph for precipitation, by anemograph for wind speed, by hygrograph for relative humidity.
Rize is located in the east of the eastern Black Sea coastline, between $40^{\circ} 22^{1}-41^{\circ} 28^{1}$ eastern meridians, and $40^{\circ} 20^{1}-41^{\circ} 20^{1}$ northern parallels. The city is surrounded by Trabzon's Of district from the West, Erzurum's İspir district from the South, Bayburt from the southwest, Artvin's Yusufeli district and Arhavi district from the east, and the Black Sea from the North.

Black Sea climate prevails in Rize. The characteristic of the Black Sea climate is that it is cool in summers, mild in winters and rainy in all seasons. The biggest factor in this is that the mountains extend parallel to the coast. The annual aveage temperature of Rize is $14{ }^{\circ} \mathrm{C}$. The annual average lowest temperature recorded in Rize to date has been determined as -7 ${ }^{\circ} \mathrm{C}$, and the highest temperature has been determined as $38,2{ }^{\circ} \mathrm{C}$. The coldest month is January with the mean value $6,7^{\circ} \mathrm{C}$, and the hottest is July with the mean value $22,9{ }^{\circ} \mathrm{C}$. Rize has the characteristic of maritime climates. Annual precipitation amount is $2301,5 \mathrm{~mm}$. Rize is the most rainy city in Turkey. Annual mean rainy days are about 183,9 (day). Precipitation in Rize is evenly distributed in all seasons and there is no dry season. The least rainfall in the province is seen in the spring and the most rainfall is seen in the autumn. Relative humidity is always above $75 \%$, generally around $80 \%$. Prevailing wind direction is in southwest direction. Annual average sunshine duration is 4,2 (hour). For Thornthwaite climate classification, the climate class of Rize is perhumid and 2nd mesothermal, whereas for Trewartha climate classification (according to universal temperature scale), summers are hot and winters are cool.

The main purpose of this study is to demonstrate the correlations as statistically significant between sunshine duration and other climate variables such as cloud cover (CLC), relative humidity (RHM), wind speed (WSP), atmospheric pressure (PRES), precipitation (PREC), maximum air temperature (MAXT), minimum air temperature (MINT) in Rize. All data were analyzed over statistical methods.

\section{Material and Method}

\subsection{Relative Sunshine Duration}

To define the relations between relative sunshine duration (RSD) and other climate variables. RSD is determined as $\mathrm{S} / \mathrm{S}_{\mathrm{o}}$ and varies 0 to $1 . \mathrm{S}$ expresses the observed value from ground-based station. $\mathrm{S}_{\mathrm{o}}$ corresponds to the daily maximum sunshine duration value which is also called daylength and is calculated by Eqn. (1). $\varphi$ demostrates the latitude angle that is between -90 and +90 . This angle depends on the given location. $\delta$ is the declination angle and is predicted via Eqn.(2). This angle is between the incoming solar rays and the equatorial plane. The expression $n$ in the formula demonstrates the Julien number of days and changes 1 to 365 . The equations (1) and (2) are determined as follows (Duffie\&Beckman, 1991; Kalogirou, 2009),

$S_{0}=\left(\frac{2}{15}\right) \cos ^{-1}(-\tan \delta \tan \varphi)$

$\delta=23.45 * \sin \left(\frac{360}{365}(284+n)\right)$ 


\subsection{Pearson Correlation Analysis}

For different sesions, each dataset was operated with Pearson correlation analysis. The values of Pearson correlation analysis were calculated to interpret the scale of pairwise relations between the computed RSD values and the observed climate variables. Pearson correlation coefficent demonstrates the direction and grade of the association between pairwise parameters. The coefficient value may be obtained as positive (between 0 and 1) or negative (between -1 and 0 ) that represents positive or negative correlations respectively. The coefficient of Pearson correlation is calculated by using the formula depicted in Equation (3),

$r(x, y)=\frac{\overline{(x-\bar{x})(y-\bar{y})}}{\sigma_{x} \sigma_{y}}$

where $\mathrm{x}$ and $\mathrm{y}$ determine the observed values, $\bar{x}$ and $\bar{y}$ demonstrate the average values of the observed values of variables $\mathrm{x}$ and $\mathrm{y}, \sigma_{x}$ describes the standard deviation of variable $\mathrm{x}$ and $\sigma_{y}$ defines the standard deviation of variable $y$. To designate the grade of the association, the coefficient of Pearson correlation may be classified as three categories named as low $(<0.49)$, moderate (between 0.49 and 0.7), high (between 0.7 and 1).

The associations for RSD and all other climate variables such as CLC, RHM, WSP, PREC, PRES, MINT, MAXT obtained from ground-based measurement station belong to Rize during the period 1960-2010 were examined over the Pearson correlation analysis technique over SPSS software package programme. In analysis, the time periods were taken as monthly sessions i.e. January to December expressed as JAN, FEB, MAR, APR, MAY, JUN, JUL, AUG, SEP, OCT, DEC. Consequently, the prominent climate variables associated with the RSD were elicited qua statistically respectable.

\section{Results and Discussion}

The statistical values such as descriptive statistics for climate variables used in this study i.e. RSD, CLC, RHM, WSP, PREC, PRES, MINT and MAXT were presented for monthly periods in Table 1 and Table 2. The Statistical parameters were presented as the values of maxium (Max), minimum (Min), standard deviation (Std. D.) and average (Mean) values for climate variables and sessions were produced. The quantities of the values for each variable were differed owing to the different sessions. For Table 1 and 2, the values of RSD has high values in summer months (JUN, JUL, AUG) whereas low values in winter months (DEC, JAN, FEB). Unlike RSD, CLC has low values in summer months and high values in winter months, as expected. RSD was related to CLC reversely. RHM has the maximum values in winter months and minimum values in summer months. The values of WSP in spring (MAR, APR, MAY) and summer were obtained as higher than autumn (SEP, OCT, NOV) and winter. For PREC, the values were high in winter and spring months and low in autumn and summer months. The PRES values were obtained as high in winter and autumn months against in spring and summer months. The values of MINT and MAXT variables have maximum degrees in summer and autumn months while minimum degrees in spring and winter months.

Table 1.Descriptive Statistics for Winter and Spring Months

\begin{tabular}{|c|c|c|c|c|c|c|c|c|c|c|c|}
\hline Month & Variable & Min. & Max. & Mean & Std. Dev. & Month & Variable & Min. & Max. & Mean & Std. Dev. \\
\hline \multirow{8}{*}{$D E C$} & RSD & 0,084 & 0,525 & 0,235 & 0,0766 & \multirow{8}{*}{$M A R$} & RSD & 0,083 & 0,412 & 0,305 & 0,0739 \\
\hline & CLC & 4,3 & 8 & 6,227 & 0,8681 & & CLC & 5 & 8,4 & 6,516 & 0,8587 \\
\hline & RHM & 56,6 & 83,6 & 74,1 & 4,9562 & & RHM & 65,6 & 84,3 & 75,11 & 4,9382 \\
\hline & WSP & 0,1 & 2 & 1,382 & 0,3525 & & WSP & 0,4 & 1,7 & 1,368 & 0,2672 \\
\hline & PREC & 52,9 & 506 & 245,3 & 89,337 & & PREC & 37,1 & 269,9 & 150,2 & 50,118 \\
\hline & PRES & 1013 & 1028 & 1018 & 2,9013 & & PRES & 1010 & 1021 & 1016 & 2,6089 \\
\hline & MINT & -4 & 5 & 0,382 & 1,9533 & & MINT & -7 & 3,4 & $-0,569$ & 2,1376 \\
\hline & MAXT & 12,8 & 26,7 & 20,42 & 3,1774 & & MAXT & 13,6 & 32,6 & 21,89 & 3,9237 \\
\hline \multirow{8}{*}{$J A N$} & RSD & 0,087 & 0,425 & 0,242 & 0,0667 & \multirow{8}{*}{$A P R$} & RSD & 0,175 & 0,483 & 0,336 & 0,0693 \\
\hline & CLC & 4,5 & 8 & 6,404 & 0,7362 & & CLC & 4,7 & 8,5 & 6,367 & 0,8595 \\
\hline & RHM & 60,2 & 83,6 & 74,01 & 5,0344 & & RHM & 65,2 & 87,1 & 76,3 & 4,887 \\
\hline & WSP & 0,2 & 1,9 & 1,4 & 0,3231 & & WSP & 0,5 & 1,7 & 1,298 & 0,2679 \\
\hline & PREC & 65,4 & 463,3 & 217,9 & 85,166 & & PREC & 26 & 213,2 & 96,96 & 42,253 \\
\hline & PRES & 1010,9 & 1026 & 1019 & 3,0294 & & PRES & 1011 & 1017 & 1014 & 1,5677 \\
\hline & MINT & $-5,4$ & 2,4 & $-0,996$ & 1,7622 & & MINT & $-2,8$ & 7 & 3,231 & 1,9783 \\
\hline & MAXT & 10,6 & 24 & 17,58 & 3,0073 & & MAXT & 17,2 & 35,8 & 26,06 & 4,1852 \\
\hline \multirow{8}{*}{$F E B$} & RSD & 0,1 & 0,419 & 0,302 & 0,0806 & \multirow{8}{*}{$M A Y$} & RSD & 0,166 & 0,549 & 0,394 & 0,0775 \\
\hline & CLC & 4,6 & 8,8 & 6,369 & 0,8394 & & CLC & 3,4 & 8,6 & 5,941 & 0,9731 \\
\hline & RHM & 58,7 & 82,1 & 73,18 & 4,5731 & & RHM & 69,3 & 86,2 & 77,69 & 4,0675 \\
\hline & WSP & 0,3 & 2 & 1,398 & 0,3056 & & WSP & 0,5 & 1,7 & 1,304 & 0,228 \\
\hline & PREC & 38,6 & 476,3 & 176,3 & 79,335 & & PREC & 23,6 & 191 & 98,75 & 44,935 \\
\hline & PRES & 1011,6 & 1024 & 1018 & 2,8275 & & PRES & 1009 & 1017 & 1014 & 1,7297 \\
\hline & MINT & $-6,4$ & 1,9 & $-1,598$ & 1,9159 & & MINT & 4,2 & 11,1 & 7,757 & 1,4787 \\
\hline & MAXT & 10 & 28,1 & 19,65 & 3,5107 & & MAXT & 21,5 & 38,2 & 27,63 & 3,4261 \\
\hline
\end{tabular}


Table 2. Descriptive Statistics for Summer and Autumn Months

\begin{tabular}{|c|c|c|c|c|c|c|c|c|c|c|c|}
\hline Month & Variable & Min. & Max. & Mean & Std. Dev. & Month & Variable & Min. & Max. & Mean & Std. Dev. \\
\hline \multirow{8}{*}{$J U N$} & RSD & 0,282 & 0,632 & 0,445 & 0,0763 & \multirow{8}{*}{ SEPT } & RSD & 0,289 & 0,546 & 0,407 & 0,0726 \\
\hline & CLC & 3,4 & 6,9 & 5,306 & 0,7806 & & CLC & 3,6 & 7,4 & 5,645 & 0,9601 \\
\hline & RHM & 65,3 & 84,2 & 76,13 & 4,3693 & & RHM & 74,5 & 84,4 & 79,55 & 2,3161 \\
\hline & WSP & 0,4 & 2,1 & 1,361 & 0,2736 & & WSP & 0,2 & 1,9 & 1,341 & 0,3864 \\
\hline & PREC & 40,8 & 250,5 & 134 & 56,619 & & PREC & 52,4 & 452,3 & 241,5 & 91,815 \\
\hline & PRES & 1007,7 & 1015 & 1012 & 1,9182 & & PRES & 1011 & 1019 & 1015 & 1,9016 \\
\hline & MINT & 7,8 & 16,4 & 12,49 & 1,8379 & & MINT & 9,2 & 17,2 & 12,73 & 1,6688 \\
\hline & MAXT & 25,2 & 35,2 & 28,64 & 2,2662 & & MAXT & 25 & 33,4 & 28,23 & 2,1216 \\
\hline \multirow{8}{*}{$J U L$} & RSD & 0,187 & 0,579 & 0,352 & 0,0826 & \multirow{8}{*}{$O C T$} & RSD & 0,215 & 0,582 & 0,386 & 0,0894 \\
\hline & CLC & 3,5 & 8,2 & 6,292 & 0,965 & & CLC & 3 & 7,4 & 5,582 & 1,0615 \\
\hline & RHM & 70,7 & 86,4 & 78,13 & 3,5476 & & RHM & 70,6 & 86,5 & 79,86 & 3,3562 \\
\hline & WSP & 0,3 & 1,7 & 1,246 & 0,2758 & & WSP & 0,2 & 2 & 1,367 & 0,4078 \\
\hline & PREC & 32,8 & 397,9 & 147,2 & 69,236 & & PREC & 8,4 & 516,6 & 286,8 & 113,6 \\
\hline & PRES & 1006,7 & 1014 & 1010 & 1,7136 & & PRES & 1013 & 1022 & 1018 & 2,1801 \\
\hline & MINT & 12 & 18,6 & 15,86 & 1,3463 & & MINT & 2,5 & 13,8 & 7,833 & 2,3189 \\
\hline & MAXT & 25,5 & 35,4 & 29,64 & 1,9866 & & MAXT & 21,8 & 33,4 & 26,35 & 2,5393 \\
\hline \multirow{8}{*}{$A U G$} & RSD & 0,176 & 0,52 & 0,377 & 0,0794 & \multirow{8}{*}{$N O V$} & RSD & 0,136 & 0,545 & 0,319 & 0,1011 \\
\hline & CLC & 4,8 & 8,5 & 6,171 & 0,8455 & & CLC & 2,3 & 8 & 5,633 & 1,2041 \\
\hline & RHM & 71,1 & 86,5 & 78,76 & 3,3795 & & RHM & 67,9 & 85,4 & 76,74 & 4,0521 \\
\hline & WSP & 0,4 & 1,8 & 1,247 & 0,3035 & & WSP & 0,2 & 2,1 & 1,433 & 0,3993 \\
\hline & PREC & 12,5 & 421,4 & 185,9 & 101,19 & & PREC & 8,2 & 507,8 & 249,7 & 121,19 \\
\hline & PRES & 1007,7 & 1016 & 1011 & 1,6884 & & PRES & 1014 & 1025 & 1018 & 2,084 \\
\hline & MINT & 13,6 & 20 & 16,4 & 1,5331 & & MINT & 0,4 & 8 & 3,618 & 2,0266 \\
\hline & MAXT & 25,7 & 34 & 29,55 & 1,7741 & & MAXT & 18,5 & 29,2 & 22,95 & 2,5293 \\
\hline
\end{tabular}

Previous to examining the dataset, the values of sunshine duration were computed and expressed as RSD values. The Pearson correlation analysis called as one of the statistical approach was handled to demonstrate the amount and direction of the relations for the RSD and the other climate parameters. The values of the Pearson correlation coefficients were shown in Table
3. The correlation values were emphasized in bold characters that found as statistically meaningful for the levels $\mathrm{p}<0.05$ and for $\mathrm{p}<0.01$. For RSD, the significant correlations were found as moderate and high levels for CLC, weak and moderate levels for RHM and PREC, weak for WSP, weak levels for PRES, MINT and MAXT.

Table 3. Pearson Correlation Coefficients for RSD over Climate Variables

\begin{tabular}{|c|c|c|c|c|c|c|c|c|}
\hline MONTH & $\begin{array}{c}\text { STATISTICAL } \\
\text { TERM } \\
\end{array}$ & CLC & RHM & WSP & PREC & PRES & MINT & MAXT \\
\hline \multirow{2}{*}{ JANUARY } & Pearson Correlation &,$- 513(* *)$ & $-0,062$ &,$- 373(* *)$ & $-0,236$ & 0,163 & 0,054 & $-0,054$ \\
\hline & Significance & 0 & 0,668 & $\mathbf{0 , 0 0 7}$ & 0,096 & 0,254 & 0,709 & 0,706 \\
\hline \multirow{2}{*}{$F E B R U A R Y$} & Pearson Correlation &,$- 725(* *)$ & $-0,028$ & 0,001 &,$- 521(* *)$ & 0,215 & 0,233 & $-0,054$ \\
\hline & Significance & $\mathbf{0}$ & 0,846 & 0,994 & $\mathbf{0}$ & 0,129 & 0,1 & 0,706 \\
\hline \multirow{2}{*}{$M A R C H$} & Pearson Correlation &,$- \mathbf{8 1 0}(* *)$ &,$- 444(* *)$ & 0,224 & $-0,057$ & 0,023 & $-0,097$ & ,325(*) \\
\hline & Significance & $\mathbf{0}$ & 0,001 & 0,114 & 0,69 & 0,872 & 0,498 & 0,02 \\
\hline \multirow{2}{*}{$A P R I L$} & Pearson Correlation &,$- 810(* *)$ &,$- 460(* *)$ & 0,109 & $-0,239$ & $-0,015$ & $-0,123$ & ,299(*) \\
\hline & Significance & 0 & 0,001 & 0,448 & 0,091 & 0,914 & 0,388 & $\mathbf{0 , 0 3 3}$ \\
\hline \multirow{2}{*}{$M A Y$} & Pearson Correlation &,$- 873(* *)$ &,$- 398(* *)$ & 0,113 & $-0,229$ & $-0,157$ & $-0,032$ & 0,261 \\
\hline & Significance & $\mathbf{0}$ & 0,004 & 0,431 & 0,106 & 0,27 & 0,826 & 0,064 \\
\hline \multirow{2}{*}{ JUNE } & Pearson Correlation &,$- 798(* *)$ &,$- 563(* *)$ & ,323(*) & $-0,16$ & 0,037 & $-0,153$ & 0,248 \\
\hline & Significance & $\mathbf{0}$ & $\mathbf{0}$ & 0,021 & 0,263 & 0,794 & 0,283 & 0,08 \\
\hline \multirow{2}{*}{$J U L Y$} & Pearson Correlation &,$- 891(* *)$ & $-0,261$ & $-0,051$ & 0,168 & $-0,255$ & 0,059 & ,369(**) \\
\hline & Significance & 0 & 0,064 & 0,72 & 0,239 & 0,071 & 0,679 & 0,008 \\
\hline \multirow{2}{*}{$A U G U S T$} & Pearson Correlation &,$- 837(* *)$ &,$- 331(*)$ & $-0,14$ & $-0,001$ & $-0,124$ & $-0,019$ & ,395(**) \\
\hline & Significance & $\mathbf{0}$ & 0,017 & 0,326 & 0,992 & 0,384 & 0,893 & 0,004 \\
\hline \multirow{2}{*}{ SEPTEMBER } & Pearson Correlation &,$- 761(* *)$ & $-0,219$ & $-0,052$ & $-0,053$ &,$- 324(*)$ & 0,069 & 0,064 \\
\hline & Significance & 0 & 0,123 & 0,717 & 0,713 & $\mathbf{0 , 0 2}$ & 0,629 & 0,656 \\
\hline \multirow{2}{*}{ OCTOBER } & Pearson Correlation &,$- 827(* *)$ &,$- 367(* *)$ & 0,104 &,$- 540(* *)$ & 0,164 & 0,142 & 0,184 \\
\hline & Significance & 0 & 0,008 & 0,466 & 0 & 0,25 & 0,319 & 0,2 \\
\hline \multirow{2}{*}{ NOVEMBER } & Pearson Correlation &,$- 699(* *)$ & 0,2 &,$- 402(* *)$ &,$- 575(* *)$ & 0,226 &, $363(* *)$ & ,296(*) \\
\hline & Significance & $\mathbf{0}$ & 0,159 & $\mathbf{0 , 0 0 3}$ & $\mathbf{0}$ & 0,11 & 0,009 & $\mathbf{0 , 0 3 7}$ \\
\hline \multirow{2}{*}{ DECEMBER } & Pearson Correlation &,$- 542(* *)$ & $-0,138$ &,$- 306(*)$ &,$- 366(* *)$ & 0,231 & 0,187 & 0,218 \\
\hline & Significance & $\mathbf{0}$ & 0,334 & 0,029 & 0,008 & 0,103 & 0,19 & 0,124 \\
\hline
\end{tabular}

**. Correlation is significant at the 0.01 level $(\mathrm{p}<0.01) \& *$. Correlation is significant at the 0.05 level $(\mathrm{p}<0.05)$. 
In Table 4, the direction of correlations between RSD and climate elements were shown for all months. There has been some exceptional cases but anyway it was seen that the correlations for
CLC, RHM and PREC were negative whereas WSP, PRES, MINT and MAXT were positive for diffrent sessions.

Table 4. Direction of Correlation for RSD

\begin{tabular}{l|c|c|c|c|c|c|c|}
\hline \multicolumn{1}{|c|}{ MONTH } & CLC & RHM & WSP & PREC & PRES & MINT & MAXT \\
\hline JANUARY & - & - & - & - & + & + & - \\
FEBRUARY & - & - & + & - & + & + & - \\
MARCH & - & - & + & + & + & - & + \\
APRIL & - & - & + & - & - & - & + \\
MAY & - & - & + & - & - & - & + \\
JUNE & - & - & + & - & + & - & + \\
JULY & - & - & - & + & - & + & + \\
AUGUST & - & - & - & - & - & - & + \\
SEPTEMBER & - & - & - & - & - & + & + \\
OCTOBER & - & - & + & - & + & + & + \\
NOVEMBER & - & + & - & - & + & + & + \\
DECEMBER & - & - & - & - & + & + & + \\
\hline
\end{tabular}

Further, the cross correlation values for climate variables were represented in Table 5-8. Table 5 shows the correlations for winter months as bold obtained statistically significant. For DEC, CLC was associated with PRES (negatively) and PREC (positively) as weak level whereas RHM with PREC (positively) as weak; WSP with MAXT (negatively) as weak; PREC with MINT (negatively) as weak; PRES with MAXT (negatively) as moderate; MINT with MAXT (positively) as weak. For JAN, the relations can be expressed as follows: CLC with PREC as weak and positive; RHM with WSP as weak and negative; PREC with MINT as moderate and negative; PRES with MINT as weak and negative; PRES with MAXT as moderate and negative. For FEB, the relations were found as; CLC with WSP, PREC and MINT as negative weak, moderate positive and negative weak respectively; while RHM with WSP as negative weak; PREC with MINT as negative weak; PRES with MAXT as negative weak.

Table 5. Cross-Correlations for Winter Months

\begin{tabular}{|c|c|c|c|c|c|c|c|c|c|}
\hline MONTH & VARIABLE & RSD & CLC & RHM & WSP & PREC & PRES & MINT & MAXT \\
\hline$D E C$ & $\begin{array}{c}\text { RSD } \\
\text { CLC } \\
\text { RHM } \\
\text { WSP } \\
\text { PREC } \\
\text { PRES } \\
\text { MINT } \\
\text { MAXT }\end{array}$ & 1 & $\begin{array}{c}-, 542(* *) \\
1\end{array}$ & $\begin{array}{c}-0,138 \\
0,215 \\
1\end{array}$ & $\begin{array}{c}-, \mathbf{3 0 6}(*) \\
0,057 \\
-0,03 \\
1\end{array}$ & $\begin{array}{c}-, \mathbf{3 6 6}(* *) \\
\mathbf{4 4 3}(* *) \\
\mathbf{3 2 7}(*) \\
0,034 \\
1\end{array}$ & $\begin{array}{c}0,231 \\
-, 280(*) \\
0,06 \\
0,207 \\
0,024 \\
1\end{array}$ & $\begin{array}{c}0,187 \\
-0,028 \\
-0,139 \\
-0,237 \\
-, 371(* *) \\
-0,262 \\
1\end{array}$ & $\begin{array}{c}0,218 \\
-0,016 \\
-0,17 \\
-, \mathbf{3 9 7}(* *) \\
-0,078 \\
-, \mathbf{5 4 0}(* *) \\
\mathbf{4 0 7}(* *) \\
1\end{array}$ \\
\hline$J A N$ & $\begin{array}{c}\text { RSD } \\
\text { CLC } \\
\text { RHM } \\
\text { WSP } \\
\text { PREC } \\
\text { PRES } \\
\text { MINT } \\
\text { MAXT }\end{array}$ & 1 & $\begin{array}{c}-, 513(* *) \\
1\end{array}$ & $\begin{array}{c}-0,062 \\
0,219 \\
1\end{array}$ & $\begin{array}{c}-, \mathbf{3 7 3}(* *) \\
0,081 \\
-, 283(*) \\
1\end{array}$ & $\begin{array}{c}-0,236 \\
\mathbf{4 5 3}(* *) \\
0,102 \\
0,084 \\
1\end{array}$ & $\begin{array}{c}0,163 \\
-0,144 \\
0,119 \\
0,066 \\
0,09 \\
1\end{array}$ & $\begin{array}{c}0,054 \\
-0,142 \\
0,065 \\
-0,116 \\
-, \mathbf{5 9 4}(* *) \\
-, \mathbf{4 5 0}(* *) \\
1\end{array}$ & $\begin{array}{c}-0,054 \\
0,035 \\
-0,09 \\
-0,209 \\
-0,124 \\
-, 663(* *) \\
, \mathbf{3 8 5}(* *) \\
1\end{array}$ \\
\hline$F E B$ & $\begin{array}{c}\text { RSD } \\
\text { CLC } \\
\text { RHM } \\
\text { WSP } \\
\text { PREC } \\
\text { PRES } \\
\text { MINT } \\
\text { MAXT }\end{array}$ & 1 & $\begin{array}{c}-, 725(* *) \\
1\end{array}$ & $\begin{array}{c}-0,028 \\
0,2 \\
1\end{array}$ & $\begin{array}{c}0,001 \\
-, 282(*) \\
-, \mathbf{4 7 9}(* *) \\
1\end{array}$ & $\begin{array}{c}\mathbf{- , 5 2 1}(* *) \\
\mathbf{, 6 5 7}(* *) \\
0,271 \\
-0,23 \\
1\end{array}$ & $\begin{array}{c}0,215 \\
-0,183 \\
-0,009 \\
-0,125 \\
-0,067 \\
1\end{array}$ & $\begin{array}{c}0,233 \\
-, \mathbf{3 1 6}(*) \\
-0,112 \\
0,087 \\
-, \mathbf{4 8 6}(* *) \\
-0,24 \\
1\end{array}$ & $\begin{array}{c}-0,054 \\
-0,083 \\
-0,258 \\
0,064 \\
-0,157 \\
-, 394(* *) \\
0,187 \\
1\end{array}$ \\
\hline
\end{tabular}

**. Correlation is significant at the 0.01 level $(\mathrm{p}<0.01) \& *$. Correlation is significant at the 0.05 level $(\mathrm{p}<0.05)$.

The cross-correlations for spring months were depicted in Table 6. For the spring months, the correlations were found as; CLC was associated with RHM (positive), WSP (negative) and MAXT (negative) in weak level; RHM with WSP (negative),
PRES (positive), MINT (positive) and MAXT (negative) as weak; WSP with PRES (negative) as weak; PREC with MINT (negative) as weak; PRES with MINT (negative) as moderate, and with MAXT (negative) as weak. 
Table 6. Cross-Correlations for Spring Months

\begin{tabular}{|c|c|c|c|c|c|c|c|c|c|}
\hline MONTH & VARIABLE & RSD & CLC & RHM & WSP & PREC & PRES & MINT & MAXT \\
\hline MAR & $\begin{array}{c}\text { RSD } \\
\text { CLC } \\
\text { RHM } \\
\text { WSP } \\
\text { PREC } \\
\text { PRES } \\
\text { MINT } \\
\text { MAXT }\end{array}$ & 1 & $\begin{array}{c}-, 810(* *) \\
1\end{array}$ & $\begin{array}{c}-, 444(* *) \\
, 438(* *) \\
1\end{array}$ & $\begin{array}{c}0,224 \\
-, 348\left(^{*}\right) \\
-, 302\left(^{*}\right) \\
1\end{array}$ & $\begin{array}{c}-0,057 \\
0,101 \\
0,072 \\
-0,156 \\
1\end{array}$ & $\begin{array}{c}0,023 \\
0,008 \\
-0,026 \\
-0,103 \\
0,096 \\
1\end{array}$ & $\begin{array}{c}-0,097 \\
0,153 \\
0,265 \\
-0,046 \\
-, \mathbf{3 2 0}\left(^{*}\right) \\
-, \mathbf{5 7 8}\left(^{* *}\right) \\
1\end{array}$ & $\begin{array}{c}\mathbf{3 2 5}\left(^{*}\right) \\
-, \mathbf{3 4 0}(*) \\
-, \mathbf{4 7 5}(* *) \\
-0,125 \\
0,038 \\
-, 295\left(^{*}\right) \\
0,191 \\
1 \\
\end{array}$ \\
\hline$A P R$ & $\begin{array}{c}\text { RSD } \\
\text { CLC } \\
\text { RHM } \\
\text { WSP } \\
\text { PREC } \\
\text { PRES } \\
\text { MINT } \\
\text { MAXT }\end{array}$ & 1 & $\begin{array}{c}-, 810(* *) \\
1\end{array}$ & $\begin{array}{c}-, 460(* *) \\
, 434(* *) \\
1\end{array}$ & $\begin{array}{c}0,109 \\
-0,252 \\
-, 461\left(^{* *}\right) \\
1\end{array}$ & $\begin{array}{c}-0,239 \\
, 355\left(^{*}\right) \\
0,122 \\
-0,009 \\
1\end{array}$ & $\begin{array}{c}-0,015 \\
0,065 \\
, \mathbf{3 2 8}\left(^{*}\right) \\
-, 399\left(^{* *}\right) \\
0,048 \\
1\end{array}$ & $\begin{array}{c}-0,123 \\
0,157 \\
0,176 \\
-0,245 \\
\left.-, 4261^{* *}\right) \\
0,13 \\
1\end{array}$ & $\begin{array}{c}\mathbf{2 9 9}(*) \\
-, \mathbf{3 4 2}(*) \\
-, \mathbf{4 4 1}(* *) \\
0,275 \\
-0,151 \\
-, 305\left(^{*}\right) \\
-0,037 \\
1 \\
\end{array}$ \\
\hline$M A Y$ & $\begin{array}{c}\text { RSD } \\
\text { CLC } \\
\text { RHM } \\
\text { WSP } \\
\text { PREC } \\
\text { PRES } \\
\text { MINT } \\
\text { MAXT }\end{array}$ & 1 & $\begin{array}{c}-, 873(* *) \\
1\end{array}$ & $\begin{array}{c}-, 398(* *) \\
, 458(* *) \\
1\end{array}$ & $\begin{array}{c}0,113 \\
-0,193 \\
-0,184 \\
1\end{array}$ & $\begin{array}{c}-0,229 \\
0,175 \\
-0,069 \\
-0,095 \\
1\end{array}$ & $\begin{array}{c}-0,157 \\
0,193 \\
0,12 \\
-0,244 \\
0,078 \\
1\end{array}$ & $\begin{array}{c}-0,032 \\
0,15 \\
, 306\left(^{*}\right) \\
0,017 \\
-0,06 \\
-0,147 \\
1\end{array}$ & $\begin{array}{c}0,261 \\
-0,207 \\
-0,166 \\
-0,161 \\
-0,195 \\
\left.-, 3961^{* *}\right) \\
0,017 \\
1 \\
\end{array}$ \\
\hline
\end{tabular}

**. Correlation is significant at the 0.01 level $(p<0.01) \& *$. Correlation is significant at the 0.05 level $(p<0.05)$.

According to Table 7, the cross-corelations for the other climate variables in summer months were expressed as; CLC was associated with RHM moderately positive, with MAXT weakly negative, with PRES weakly positive; RHM was related to WSP weakly negative; WSP was correlated to MAXT weakly positive in JUN and negative in AUG; PRES was associated with MINT and MAXT weakly negative; MINT was related to MAXT weakly positive.

Table 7. Cross-Correlations for Summer Months

\begin{tabular}{|c|c|c|c|c|c|c|c|c|c|}
\hline MONTH & VARIABLE & RSD & CLC & RHM & WSP & PREC & PRES & MINT & MAXT \\
\hline JUN & $\begin{array}{c}\text { RSD } \\
\text { CLC } \\
\text { RHM } \\
\text { WSP } \\
\text { PREC } \\
\text { PRES } \\
\text { MINT } \\
\text { MAXT } \\
\end{array}$ & 1 & $\begin{array}{c}-, 798(* *) \\
1\end{array}$ & $\begin{array}{c}-, 563(* *) \\
, 511(* *) \\
1\end{array}$ & $\begin{array}{c}, 323(*) \\
-0,214 \\
-, 345\left(^{*}\right) \\
1\end{array}$ & $\begin{array}{c}-0,16 \\
0,083 \\
0,187 \\
-0,023 \\
1\end{array}$ & $\begin{array}{c}0,037 \\
0,129 \\
-0,07 \\
-0,114 \\
-0,126 \\
1\end{array}$ & $\begin{array}{c}-0,153 \\
0,14 \\
0,102 \\
-0,108 \\
-0,126 \\
-, 313\left(^{*}\right) \\
1\end{array}$ & $\begin{array}{c}0,248 \\
-, 338(*) \\
-0,167 \\
, 400\left(^{* *}\right) \\
-0,038 \\
-, 408(* *) \\
0,197 \\
1 \\
\end{array}$ \\
\hline$J U L$ & $\begin{array}{c}\text { RSD } \\
\text { CLC } \\
\text { RHM } \\
\text { WSP } \\
\text { PREC } \\
\text { PRES } \\
\text { MINT } \\
\text { MAXT } \\
\end{array}$ & 1 & $\begin{array}{c}-, 891(* *) \\
1\end{array}$ & $\begin{array}{c}-0,261 \\
0,26 \\
1\end{array}$ & $\begin{array}{c}-0,051 \\
0,059 \\
-, 287(*) \\
1\end{array}$ & $\begin{array}{c}0,168 \\
-0,134 \\
0,057 \\
-0,216 \\
1\end{array}$ & $\begin{array}{c}-0,255 \\
, 350\left(^{*}\right) \\
0,116 \\
0,011 \\
0,064 \\
1\end{array}$ & $\begin{array}{c}0,059 \\
-0,054 \\
-0,107 \\
-0,171 \\
-0,109 \\
-, 366(* *) \\
1\end{array}$ & $\begin{array}{c}, 369\left(^{* *}\right) \\
-, 405\left(^{* *}\right) \\
-0,107 \\
0,021 \\
-0,19 \\
-, 323\left(^{*}\right) \\
, 353\left(^{*}\right) \\
1 \\
\end{array}$ \\
\hline$A U G$ & $\begin{array}{l}\text { RSD } \\
\text { CLC } \\
\text { RHM } \\
\text { WSP } \\
\text { PREC } \\
\text { PRES } \\
\text { MINT } \\
\text { MAXT }\end{array}$ & 1 & $\begin{array}{c}-, 837\left(^{* *}\right) \\
1\end{array}$ & $\begin{array}{c}-, 331(*) \\
0,211 \\
1\end{array}$ & $\begin{array}{c}-0,14 \\
0,143 \\
-0,236 \\
1\end{array}$ & $\begin{array}{c}-0,001 \\
0,132 \\
0,114 \\
0,002 \\
1\end{array}$ & $\begin{array}{c}-0,124 \\
0,188 \\
-0,045 \\
-0,066 \\
-0,083 \\
1\end{array}$ & $\begin{array}{c}-0,019 \\
-0,016 \\
0,08 \\
-0,08 \\
-0,193 \\
-, 386(* *) \\
1\end{array}$ & $\begin{array}{c}.395\left(^{* *}\right) \\
-, 36\left(^{* *}\right) \\
0 \\
-, 416\left(^{* *}\right) \\
0,097 \\
-, 453\left(^{* *}\right) \\
, 298\left(^{*}\right) \\
1\end{array}$ \\
\hline
\end{tabular}

**. Correlation is significant at the 0.01 level $(p<0.01) \& *$. Correlation is significant at the 0.05 level $(p<0.05)$. 
The pairwise relations for cross-correlations of variables in autumn months were demonstrated in Table 8 qua; for CLC and other variables, CLC was related to PRES positive weak, PREC positive weak and moderate, MINT negative weak; for RHM and other climate elements, RHM was associated with WSP negative weak; For WSP, it was correlated with MINT and MAXT negative weak, PREC positive weak; for PREC, it was related to MINT negative weak and moderate levels; for PRES, it was correlated to MINT and MAXT negative weak; finally MINT and MAXT were correlated positively as weak.

Table 8. Cross-Correlations for Autumn Months

\begin{tabular}{|c|c|c|c|c|c|c|c|c|c|}
\hline MONTH & VARIABLE & RSD & CLC & RHM & WSP & PREC & PRES & MINT & MAXT \\
\hline$S E P$ & $\begin{array}{c}\text { RSD } \\
\text { CLC } \\
\text { RHM } \\
\text { WSP } \\
\text { PREC } \\
\text { PRES } \\
\text { MINT } \\
\text { MAXT }\end{array}$ & 1 & $\begin{array}{c}-.761(* *) \\
1\end{array}$ & $\begin{array}{c}-0,219 \\
0,112 \\
1\end{array}$ & $\begin{array}{c}-0,052 \\
0,095 \\
-0,265 \\
1\end{array}$ & $\begin{array}{c}-0,053 \\
0,196 \\
0,001 \\
-0,086 \\
1\end{array}$ & $\begin{array}{c}-, \mathbf{3 2 4}(*) \\
\mathbf{3 7 9}(* *) \\
0,046 \\
-0,076 \\
-0,226 \\
1\end{array}$ & $\begin{array}{c}0,069 \\
-0,103 \\
0,03 \\
-, \mathbf{3 0 3}\left(^{*}\right) \\
-0,183 \\
-, 282\left(^{*}\right) \\
1\end{array}$ & $\begin{array}{c}0,064 \\
-0,113 \\
-0,098 \\
-0,05 \\
0,046 \\
-, 417\left(^{* *}\right) \\
.336\left(^{*}\right) \\
1\end{array}$ \\
\hline$O C T$ & $\begin{array}{c}\text { RSD } \\
\text { CLC } \\
\text { RHM } \\
\text { WSP } \\
\text { PREC } \\
\text { PRES } \\
\text { MINT } \\
\text { MAXT } \\
\end{array}$ & 1 & $\begin{array}{c}-, 827(* *) \\
1\end{array}$ & $\begin{array}{c}-, 367(* *) \\
, 354\left(^{*}\right) \\
1\end{array}$ & $\begin{array}{c}0,104 \\
-0,108 \\
-, 428\left(^{* *}\right) \\
1\end{array}$ & $\begin{array}{c}-, \mathbf{5 4 0}(* *) \\
. \mathbf{4 2 4}(* *) \\
0,221 \\
0,045 \\
1\end{array}$ & $\begin{array}{c}0,164 \\
-0,009 \\
-0,045 \\
-0,158 \\
-0,067 \\
1\end{array}$ & $\begin{array}{c}0,142 \\
-0,099 \\
-0,02 \\
-0,215 \\
-, \mathbf{4 3 4}(* *) \\
-, \mathbf{3 4 8}\left(^{*}\right) \\
1\end{array}$ & $\begin{array}{c}0,184 \\
-0,224 \\
-0,237 \\
0,162 \\
-0,03 \\
-, 429\left(^{* *}\right) \\
0,106 \\
1 \\
\end{array}$ \\
\hline $\mathrm{NOV}$ & $\begin{array}{c}\text { RSD } \\
\text { CLC } \\
\text { RHM } \\
\text { WSP } \\
\text { PREC } \\
\text { PRES } \\
\text { MINT } \\
\text { MAXT }\end{array}$ & 1 & $\begin{array}{c}-, 699(* *) \\
1\end{array}$ & $\begin{array}{c}0,2 \\
-0,039 \\
1\end{array}$ & $\begin{array}{c}-, 402(* *) \\
0,16 \\
-, 396\left(^{* *}\right) \\
1\end{array}$ & $\begin{array}{c}-, 575\left(^{* *}\right) \\
, \mathbf{5 8 3}(* *) \\
-0,106 \\
, \mathbf{3 0 6}(*) \\
1\end{array}$ & $\begin{array}{c}0,226 \\
-0,022 \\
-0,142 \\
-0,107 \\
-0,154 \\
1\end{array}$ & $\begin{array}{c}., 363(* *) \\
-, 446\left(^{* *}\right) \\
0,114 \\
-, 330(*) \\
-, 685\left(^{* *}\right) \\
0,156 \\
1\end{array}$ & $\begin{array}{c}. \mathbf{2 9 6}\left(^{*}\right) \\
-0,229 \\
-0,135 \\
-, 328\left(^{*}\right) \\
-0,228 \\
-, 338\left(^{*}\right) \\
0,133 \\
1 \\
\end{array}$ \\
\hline
\end{tabular}

**. Correlation is significant at the 0.01 level $(\mathrm{p}<0.01) \& *$. Correlation is significant at the 0.05 level $(\mathrm{p}<0.05)$.

The obtained findings were revealed that the RSD was associated with other climate variables in spite of the grade of significance was varied for each time period. The prediction of RSD was not the main content of the present work, however this settlement may be analyzed and discussed in subsequent studies.

\section{Conclusions and Recommendations}

In this study offered that, RSD was associated with other climate variables over diverse grades owing to the monthly sessions. Daily valus for each climate variable were transformed to monthly average daily values during 1960-2010 and then each dataset was examined with Pearson correlation analysis technique. The pairwise relations for RSD and the other climate variables were obtained generally as weak, moderate and high grades. RSD was related to the climate elements as expressed; for CLC as moderate and high levels, for RHM as weak and moderate, for WSP as weak, for PREC as weak and moderate, for PRES as weak, for MINT as weak and moderate, for MAXT as weak. Additionally, the cross-correlations differed in direction such as positive or negative and magnitude i.e. weak, moderate and high but found as weak or moderate for each month.

According to the monthly sessions of the period 1960-2010, there were obtained the correlations as statistically meaningful among the RSD and the climate variables mentioned above.
Eventually, it was seen that the RSD was negatively related to cloud cover, the amount of precipitation and the relative humidity while pointed out that it was positively associated with the atmospheric pressure, wind speed, minimum and maximum air temperatures except the found exceptional cases.

Furthermore, atmospheric circulations and topography of a given location are associated with RSD spatially. Additionally, urban planning and urbanization rate, the emissions of air pollutants in atmosphere originated from natural and anthropogenic sources have influences on the RSD.

\section{Acknowledge}

The author wish to thank for supplying the climatological data to the Turkish State Meteorological Service.

\section{References}

Aksoy, B. (1999). Analysis of Changes in Sunshine Duration Data for Ankara, Turkey. Theoretical and Applied Climatology, 64, 229-237.

Aksoy, B. (2010). Solar radiation over Turkey and its analysis. International Journal of Remote Sensing. https://doi.org/10.1080/01431161.2010.508056. 
Angell J.K., Korshover, J., \& Cotton, G.F. (1984). Variation in United States Cloudiness and Sunshine, 1950-82. Journal of Applied Meteorology, 23, 752-761.

Duffie J. A. \& Beckman, W. A. (1991). Solar Engineering of Thermal Processes. John Wiley \& Sons, New York, NY, USA, 2nd edition.

Essa, K. S., \& Etman, M. S., (2004). On the Relation Between Cloud Cover Amount and Sunshine Duration. Meteorology and Atmospheric Physics, 87, 235-240.

Kalogirou, S.A. (2009). Solar Energy Engineering Processes and Systems. Elsevier Inc, Amsterdam, The Netherlands,1st edition.

Palle, E., \& Butler, C.J., (2001). Sunshine Records From Ireland: Cloud Factors and Possible Links to Solar Activity and Cosmic Rays. International Journal of Climatology, 21, 709729. https://doi.org/10.102/joc.657.

Robaa, S.M. (2008). Evaluation of Sunshine Duration From Cloud Data in Egypt. Energy, 33(5), 785-795.

Sanchez-Lorenzo, A., Calbo, J., Brunetti, M., \& Deser, C. (2009). Dimming/brightening over the Iberian Peninsula: trends in sunshine duration and cloud cover and their relations with atmospheric circulation. Journal of Geophysical Research D: Atmospheres, 114(10), Article ID D00d09.
Weber, G.R. (1994). On the Seasonal Variation of Local Relationships Between Temperature, Temperature Range, Sunshine and Cloudiness. Theoretical and Applied Climatology, 50(1-2), 15-22.

You, Q., Kang, S., Flugel, W.A., Lorenzo, A.S., Yan, Y., Huang, J., \& Vide, J.M. (2010). From Brightening to Dimming in Sunshine Duration over the Eastern and Central Tibetan Plateau (1961-2005). Theor. Appl. Climatol. 101, 445-457.

Yang, Y.H., Zhao, N., Hao, X.H., \& Li, C.Q. (2009a). Decreasing trend of sunshine hours and related driving forces in North China. Theor. Applied Climatology, 97,91-98, https://doi.org/10.1007/s00704-008-0049-X.

Yang, Y., Zhao, N., Hu, Y., \& Zhou, X. (2009b). Effect of Wind Speed on Sunshine Hours in Three Cities in Northern China. Climate Research, 39, 149-157, https://doi.org/10.3354/cr00820.

Zateroglu, M.T. (2021a). Assessment of the Effects of Air Pollution Parameters on Sunshine Duration in Six Cities in Turkey. Fresenius Environmental Bulletin. 30(02A), 22512269.

Zateroglu, M.T. (2021b). The Role of Climate Factors on Air Pollutants $\left(\mathrm{PM}_{10}\right.$ and $\left.\mathrm{SO}_{2}\right)$. Fresenius Environmental Bulletin. 30(11), 12029-12036. 